Research Article

Joanna Markiewicz

\title{
Value Creation by Support Organizations Through the Prism of Conflicting Institutional Logics
}

https://doi.org/10.2478/ijme-2018-0011

Received January 9, 2018; accepted May 5, 2018

\begin{abstract}
The article sets out to explore how conflicting institutional logics of support organizations influence their value creation. Value creation undertaken by support organizations does not directly reflect their missions. Even though one can generalize that all support organizations should adjust their offer according to the idea of helping companies (especially small- and medium-sized enterprises [SMEs]) in their development, support organizations very often struggle with the conflict between mission delivery and survival needs, which affects value proposition of services. Moreover, support organizations are also shaped by institutional logics, which, embedded in social systems, govern all social agents. Therefore, the study explains the challenge of value creation from the perspective of the conflict of competing institutional logics that govern support organizations. The study also has its academic impact by contributing to existing literature on value creation by support organizations through the use of institutional logic theory. To gain this knowledge, discourse analysis is utilized in the study.
\end{abstract}

Keywords: institutional logics, support organizations, support services, value creation JEL codes: L31, L84, D46, Z13

\section{Introduction}

The main aim of support organizations is to deliver support services for small- and medium-sized enterprises (SMEs) in order to boost their development. The nature of support organizations is diverse - some support organizations are connected with public bodies, so they are dependent on regional or local institutions. Others belong to the third sector (called "nonprofit organizations [NPOs]") and are associated with bottom-up initiatives and charitable missions to serve SMEs. They all have to face survival and development needs. These strands reflect in the complex nature of institutional logics enacted by support organizations. On the one hand, adjustment to the expectations of the main income provider (government/regional authority, bodies managing European Union [EU] money, or founders) can be observed. On the other hand, support organizations are established to support and help SMEs, so they should be able to meet the changing market needs and current expectations of their main customers, to be efficient in their support provision. Therefore, the main aim of the article is to examine how struggling with the conflict between mission delivery and survival needs affects the value proposition of services and also, hence, how conflicting institutional logics of support organizations influence value creation. To gain this knowledge, qualitative research based on semistructured interviews is utilized in the study. The study also has its academic impact by contributing to existing literature on value creation by support organizations through the use of institutional logic theory.

*Corresponding author: Joanna Markiewicz, The Faculty of Economics and Management, University of Szczecin, 64 Mickiewicza Street, 71-101 Szczecin, Poland, E-mail: brazuk.joanna@gmail.com, joanna.markiewicz@usz.edu.pl 
Taking these facts into account, the article is organized in the following way: the first theoretical part presents the nature of support organizations, emphasizing their sectoral duality. The second theoretical part presents the basis of institutional theory in relation to support organizations. The study then explains the challenge of value creation from the perspective of the conflict among competing institutional logics that govern support organizations. In this part, two propositions are also indicated. The presentation of the findings of the research is preceded by the justification of the method of discourse analysis. The study closes with the Conclusion. showing the main contributions of the study.

\section{The Complex Nature of Support Organizations}

\subsection{Sectoral Duality}

Support organizations constitute one of the tools used by governments to foster the development of enterprises, especially microenterprises and SMEs [Hailey, 1985; Markiewicz, 2010]. Support organizations provide services "originating in a public policy initiative, that aim to assist enterprises or entrepreneurs to successfully develop their business activity and to respond effectively to the challenges of their business, social, and physical environment" [European Commission, 2001, p. 12]. Two types of services can be distinguished: 1) technical, including, e.g., consultancy, trainings; and 2) financial, including, e.g., preferential credits and loans, grants. The fundamental principles of the business support service provision should involve client orientation, comprehension and rationalization, high quality, and adjustment to the modern economy [European Commission, 2001]. The functioning of support organizations and the provision of support services create a support system. Such a system is a part of creating a businessfriendly environment, which also encompasses interactions between government and enterprises in terms of taxation, administration, and legal regulations.

Country characteristics emerging from social, economic, and political conditions affect the nature of support organizations. Quangos and NPOs are the most dominant types of support organizations, in both countries included in the study. To describe quangos, various terms are used such as "quasi-autonomous nongovernmental organizations (NGOs)", "quasi-government”, or "semiautonomous authorities". There is no agreed definition of quangos [Doig, 1979; Bochel and Bochel, 2004]. McGarvey and Cairney [2008, p. 143] pointed out that they are "government bodies at arm's length from government, 'sponsored' and overseen by government department". These organizations are responsible for the delivery of public services, but in contrast to the government, a degree of independence makes them more "democratic" [Flinders, 2004]. "Quangos" is the term used in the UK. In Poland, one would rather define this kind of organizations as units of the public finance sector, as defined in the Public Finance Act [Dz.U, 2009]. Hence the examples of Polish quangos operating in the business support system can be enterprise agencies, technology centers operating within universities, industrial parks, and so on.

NPOs belong to the third sector. As Gunn underlined [2004, p. vii, 1, 6], the third sector depicts "organizations in the economy which are neither for-profit business nor government agencies (...). NPOs fall into two broad categories: some serve only their members, and others perform a broad array of public services.(...) The first group includes social clubs, political parties, labour unions, business associations and cooperatives". On the face of it, the distinction between market sector and third sector is clear. Private sector practices are focused on demand, which generates profit, whereas the third sector is needs-oriented and should lead to financial and social return. This, of course, influences the strategy approach, which in private businesses can be characterized as being led by product/market, while in NPOs, it is mainly driven by need/ competences/value. Dissimilarity can be also perceived in culture, which - for business - means viability and independency. NPOs' culture can be described as more dependent and grant-driven [Bridge et al., 2014].

In practice, NPOs exhibit a hybrid nature. Many scholars point out that the line between commercial and public organizations is blurring [Hammack and Young, 1993]. This sectoral convergence is called "mixed social economy" [Knapp et al., 1997; Ferris and Graddy, 1999] and include for-profit, nonprofit, and governmental institutions. 
The blurring of lines between commercial and public organizations can be also explained by the evolution in public governance. As Osborne [2006] argues, the shift from the nature Public Administration (PA) through New Public Administration to New Public Governance has resulted in the change from the statist and bureaucratic tradition to the embryonic and pluralist tradition. Increased consumerism and market-like arrangements, together with pubic management practice, create hybrid forms in the public management sector [Clarke et al., 2007]. Such an evolution is reflected in the engagement of NPOs in public life and policy implementation.

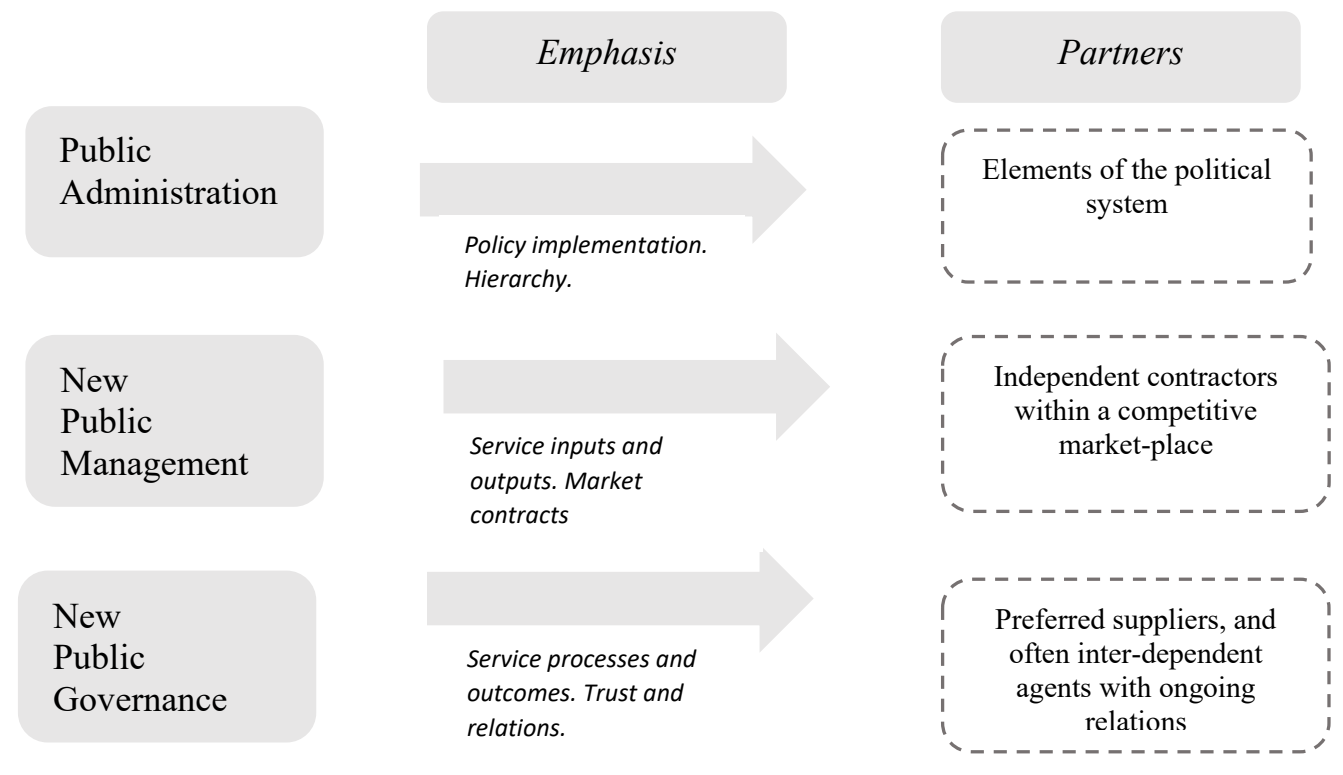

Figure 1. Influence of the nature of public sector management on the choice of partners in the context of engagement of business support organizations. Source: Osborne, Stephen P., The New Public Governance? Public Management Review, 09/2006, Volume 8, Issue 3, p. 383.

Analyzing the engagement of external partners (Figure 1), one can notice that in the case of NPOs, despite the distance from political entities, relations or interdependency is preferred in the choice of external partners. Considering business support organizations, such an approach can be seen in the increased engagement of quangos ${ }^{1}$ in the UK. In the Polish context, political changes connected with rejecting "only market orientation" mainly affected the rules and potential groups of beneficiaries applying for EU funds ${ }^{2}$.

\subsection{Institutional Logics of Support Organizations}

In order to analyze the value creation by support organizations considering their complex nature, the institutional logics theory is used in this article. Institutional logics that govern organizations are helpful to understand the challenges that support organizations have to face in combining mission delivery and market survival and thus study how institutional logics influence the value offered for their clients.

The concept of institutional logics is closely related with institutions and institutional fields. Institutional logics define the main principles that guide the field participants. The idea of institutional logics was the answer on how to combine the concept of institutions, defined inter alia by North [1990] or Veblen [1989],

1 Growth in the role of quangos can be presented by the increase from $£ 41.6$ billion in 1978/79 to £61.6 billion in 1994/95 [Bochel and Bochel, 2004, p. 143]

2 Over 1.8 billion PLN was received by Polish third sector from the UE regional programmes. Third sector became a $4^{\text {th }}$ beneficiary of the UE money in 2014-2020 perspective. 
with organizations. The academic world has been making attempts to explain how organizations respond to various forces from the environment and from internal arrangements. Some scholars have highlighted the influence of various external demands [Selznick, 1949], and some have indicated that organizations need to respond to expectations of internal groups [Ceyert and March, 1963]. One of the solutions comprised institutional logics, which encompass a set of material practices and symbolic constructs [Friedland and Alford, 1991; Thornton and Ocasio, 1999, 2008; Thornton et al., 2012]. Friedland and Alford [1991] distinguish the main societal logics of democracy, capitalism, state, family, and religion, while Thornton and Ocasio [2008] identify state, market, profession, corporation, family, religion, and community. Others point the influence of factors such as history, geography, and culture associated with the environment in which the organization operates [Greenwood et al., 2010] or key resource providers [Jones et al., 2012].

In order to examine value creation by support organizations, this study uses the definition of institutional logics coined by Thornton and Ocasio [1999, p. 804], who depict them as "socially constructed, historical patterns of material practices, assumptions, values, beliefs, and rules”.

This presence of multiple logics is perceived by scholars in various contexts. Some academics underline coexistence, which makes organizations more adaptable to the field level [Reay and Hinings, 2009], whereas some emphasize the hybridity [Battilana and Dorado, 2010; Jay, 2012; Pache and Santos, 2013]. Greenwood et al. [2011] depict the coexistence of multiple institutional logics as institutional complexity, while Knutsen [2012] proposes the idea of adapted institutional logics, which should be understood as an overtaking of innate institutional logics by external institutional logics.

For the purpose of this study, the concept of conflicting institutional logics shaping the hybridity of organizations [Battilana and Dorado, 2010] is used. Battilana and Dorado [2010] argue that organizations that have to struggle with tensions between conflicting institutional logics can maintain their hybrid nature. Based on the example of new microfinance organizations, which were established as spin-offs from NGOs, they showed how they could reconcile the banking logics with the development logics of helping the poor to get access to finance. The authors emphasize the challenge to maintain hybridity as it can "trigger internal tensions that may generate conflicts among organization members, who are ultimately the ones who enact institutional logics” [Battilana and Dorado, 2010, p. 1420].

The conflicting institutional logics shaping hybrid organizations seem to fit the nature of support organizations encompassing NPOs and quangos. NPOs are often depicted by scholars as "hybrids" combining the nature of private and public organizations [Evers, 2005; DiMaggio, 2006]. There is also a debate concerning quangos, mainly about their identity and role in delivering public services. Due to their partial independency and unaccountability, they cannot be only seen through the lenses of the state and delivering policy. There has been criticism concerning their consumerist approach to public services [Wright, 1994] and their dependency on various stakeholders, from individual board members to users and external stakeholders [Skelcher, 1998].

To analyze the conflict of institutional logics in support organizations, the approach proposed by Friedland and Alford [1991] is utilized herein. They recognized three main types of logics enacted by organizations: state, democracy, and capitalism. The logic of capitalism assumes accumulation and commodification of human activity and converting this activity to a price. The basis of the logic of democracy encompasses citizen participation and popular control over human activity. The pillars of the logic of the state lie in legal and bureaucratic hierarchies and also in regulation of human activity [Thornton et al., 2012]. Democracy is associated with quangos, mainly because of their participation in public governance. But it can also be associated with NPOs, which very often are grassroots initiatives with the mission to help in a specific area of human activity. Quangos demonstrate the logic of the state (delivery of government strategy), as do many NPOs (dependency on public program). The logic of capitalism can explain the behavior of some support organizations as they all have to respond to market needs and be effectively governed in order to survive and develop. Both NPOs and quangos seem to exercise the logic of professions [Thornton and Ocasio, 2008], as they need to be specialized in providing services for business.

The institutional logics of business support organizations are also shaped by their sectoral orientation. Public orientation is definitely observed in quangos. But in Poland, some support organizations are public sector oriented, especially those that were created to help specific branches, e.g., where big, state-owned 
companies dominate. Many business support organizations appointed at higher education institutions also represent the public sector orientation. Private sector orientation tends to be enacted by those support organizations that provide help mainly to the SME sector and often compete with commercial consulting companies in offering support services. Such organizations have to be flexible and react to changing market conditions, which does not exclude the fact that they also benefit from state/EU programs. In both cases, the conflict between state and capitalism logics is observed. The private sector-oriented business support organizations sometimes adjust their offer to EU/state programs in order to gain financial resources, whereas public sector-oriented ones have to enact efficiency orientation in order to provide substantiation for their services.

The explanation of rising marketization of those business support organizations that represent the nonprofit sector can be explained by the resource dependency theory [Pfeffer and Salancik, 1978]. As Eikenberry and Kluver [2004] stated, such marketization can bring, for NPOs, short-term benefits, but in the long-term perspective, it can be harmful for civil society. Another theory that can contribute to the explanation of the conflict between mission orientation and survival needs is the contingency theory. According to this theory, only those organizations whose characteristics fit with the contingencies are able to be effective [Donaldson, 2001; Bradshaw, 2009]. No strategy and characteristics are good if contingencies change; therefore, the structure of the organization has to adapt to external environment. Furthermore, population ecology theory can bring valuable insights to the development of business support organizations. The theory assumes that survival of organizations is based on environmental selection. This means that organizations that can adjust to a specific environment would survive and will be a part of the organization population [Hannan and Freeman, 1977; Carroll, 1988; Manjula and Raymond, 2011]. Institutional logic standpoint, together with the herein-mentioned theories, is helpful to understand the dual nature of business support organizations, which affects their value creation.

\section{Value Creation Facing Conflicting Institutional Logics}

Support organizations are perceived to have a mission to serve business. This charitable perception is mainly associated with providing services for free or at a preferential and affordable price compared to average market fees. This is usually stated in statutory documents, such as statutes, missions, or strategies, constituting pillars for the functioning of support organizations. The goals of support organizations are imposed by the individuals or bodies that establish these organizations. In the case of NPOs, it can be individuals or legal entities that organize their mission-related activity in legal forms such as associations, chambers of commerce, foundations, or even commercial companies ${ }^{3}$. Quangos emerge from public bodies and usually enact a form of agencies, funds, or bodies separate from the parent organizations (e.g., innovation centers created at universities).

Taking these considerations into account, members and bodies that have established support organizations define the vision of provision of services for business and the value of these services. Such visions are mainly related with the accessibility, meeting the business needs, professional value, and impact on economic development on the region/country. On the other hand, support organizations have to face the real economic challenges related with survival needs and the rapidly changing economic reality, imposing various expectations from their main clients, i.e., businesses.

The question "How is value creation by support organizations affected by the conflict between the mission-related approach and survival approach?" remains crucial in this study. To answer this question, it is necessary to focus on the issue of value creation itself. Value creation is vital for organizations. Identifying the target group of support organizations and choosing appropriate value for them constitute the basis for entering markets. According to Rintamaki et al. [2007], value proposition encompasses economic value

3 Polish legislations allows commercial companies to gain the title of public benefit organisations providing that the statutory documents explicitly state that all benefits should contribute to the achievements of organisations' goals, and should not be distributed among owners or shareholders. 
(related with price), functional value (reflecting specific functional needs), symbolic value (connected with self-expression needs), and emotional value (based on experimental needs). Payne and Frow [2014, p. 240], argue that "value proposition is an organisation's offering to customers, representing a promise of benefits of value that customers will receive during and after the usage experience. It identifies both product and experiential benefits and costs (or sacrifices) that result from the relationship between customer and organisation. A superior value proposition represents an offering to customers that adds more value or solves a problem better than other similar competitive offerings".

One may say that the main principles shaping the support organizations' services is the help for business, especially targeting microcompanies and SMEs (perceived as a disadvantaged population of companies compared to big corporations). Based on this assumption, support organizations should provide services for SMEs that are accessible, of high quality, and are professional, as well as meet the business needs emerging from the turbulent environment. These mission-related values may face the limitations resulting from common survival needs related to access to finance or human resources. To deliver services, appropriate resources should be utilized. In a majority of support organizations, employees are the most important as they deliver training or consulting services for businesses. In the case of support organizations based on more tangible offers, such as letting premises, people are still very important resources as they deliver support related to running a business or implementing new technology (in business incubators or technology parks). Therefore, all types of support organizations have to employ a sufficient number of employees, who should have professional knowledge in order to offer professional support and have to provide appropriate trainings to the staff for increasing their competences. In order to meet the expectation of entrepreneurs concerning sectoral new technology trainings, support organizations very often have to hire well-known specialists from the market. One should remember that in the majority of cases, support organizations do not earn money from such activities ${ }^{4}$. Hence, on the one hand, support organizations are expected to offer high quality of services that meet the current market needs of the businesses. On the other hand, survival and development needs of support organizations constrain the mission-related orientation and define limitations to the value proposition of services. These mentioned arguments are the bases for the first preposition.

Proposition 1. The value of services provided by support organizations is affected by the conflict emerging from the overlapping of resource dependency and prevention of drift from the mission.

Referring to the Friedland and Alford's [1991] concept of various logics enacted by organizations and the hybridity of support organizations, value creation can be influenced by competing institutional logics of the state, democracy, and capitalism. The existing literature states that some NPOs exercise the logics of democracy as they reflect the civil society concept [Knutsen, 2012]. This may imply that these support organizations that belong to the third sector are open for every business, as they should represent the approach of equality and accessibility. But many support organizations, in order to get external funds for their survival and development, decide to cooperate with commercial entities (e.g., banks), who pay for trainings and usually provide their trainers but expect in return that participants will meet their potential target group criteria. In such cases, they enact business logic. Support organizations belonging to the NPO group also exercise the logic of the state, when the value of their offer is based on the frames of the funding programs that finance the activities of these support organizations through various projects. In such cases, many support organizations are forced to offer the value assumed in the funding programs instead of the value expected by business.

Quangos functioning as support organizations apparently enact the logic of the state, as they are mainly responsible for the delivery of the state or regional development strategy. They are also perceived to enact the logic of democracy, as they should provide services for all businesses that need help. In reality,

4 Most of services provided by support organisations are free. If any fee is charged it should be preferential and affordable price compering to average market fees. This money should cover part of the costs related with paid services. 
many strategies are focused on selected sectors, and funding bodies are very result oriented. Therefore, such support organizations only help those businesses that are likely to achieve the assumed results (concerning, e.g., increase of employment, entering foreign markets, or investing in new technologies). As a consequence, the value of services is also interrelated with the achievement of the results, which makes such support organizations exercise also the logic of capitalism. This leads to the following second preposition:

Proposition 2. The value proposition of services offered by support organizations is influenced by the conflict among the logics of the state, capitalism, and democracy.

\section{Method}

The research design guiding this empirical study is based on qualitative research. In order to explore the conflicting institutional logics of business support organizations and find how this influences their value creation, discourse analysis is utilized. The plan of the research assumed reaching support organizations of at least two cities located in different parts of Europe. This research was part of a bigger research conducted in Szczecin and Glasgow (in May 2014 and May 2015'5), the main aim of which was to explore and compare the business models of business support organizations that function in Szczecin and Glasgow and that provide services for creative industries. The research on value creation was introduced to all potential organizations from Szczecin and Glasgow. Only six organizations accepted the invitation to the research and consented to take part in interviews.

Semistructured interviews were conducted among the six support organizations (three from Glasgow and three from Szczecin). The interviewees were recruited from the management level; therefore, chief executive officers (CEOs) or managers of departments were interviewed. In order to ensure that interviewees had enough experience and knowledge about their organizations' functioning, only those managers who had been employed by their organization for at least 3 years were invited to the interview. No other information was collected about interviewees. Information about the business support organizations that took part in the research is presented in Table 1.

Table 1. The Characteristics of Support Organizations Included in the Research

\begin{tabular}{llllll}
\hline I Identification & Glasgow & Identification & & Szczecin & \\
\cline { 2 - 3 } \cline { 5 - 5 } & Type of organization & Type of services & & Type of organization & Type of services \\
\hline $1 G$ & NPO & Generic & $1 S$ & NPO & Generic \\
$2 G$ & NPO & Sector specific & $2 S$ & NPO & Generic \\
$3 G$ & Quango & Generic & $3 S$ & Quango & Sector specific \\
\hline
\end{tabular}

Source: Author.

Discourse analysis, used in this study, enabled exploration of the data collected through the semistructured interviews. To explain the idea of discourse analysis, it is worth citing du Gay [2000, p. 67], who argues that discourse analysis "is a group of statements that provide a way of talking about and acting upon a particular object. When statements about an object or topic are made from within a certain discourse, that discourse makes it possible to construct that object in a particular way". The broad understanding of discourse analysis makes this term vague, as some academics relate it with historical studies and others with critical analysis. Grant stated that discourse analysis is the "structured collection of texts embodied in the practices of talking and writing (as well as a wide variety of visual representations and cultural

5 The research was conducted thanks to the Junior Dekaban-Liddle Fellowship and Senior Dekaban-Liddle Fellowship on the University of Glasgow in Scotland which the author was awarded in 2014 and 2015 
artifacts) that bring organizationally related objects into being as these texts are produced, disseminated and consumed" [Grant et al., 2004, p. 3]. One can say that discourse analysis indeed encompasses wide, multiple, and heterogeneous areas. This is its advantage, as it can be utilized to investigate various topics such as organizational logics [Spicer and Sewell, 2010], institutions [Phillips et al., 2004], or strategy [Vaara et al., 2010]. Therefore, I assume that discourse analysis contributes to a cognizance of the role of institutions that shape the relations between social actors and influence the institutional logics enacted by organizations. They are revealed in meanings and understandings that dominate in social lives. To prove this approach, I would like to refer to Hardy and Phillips' arguments [Hardy and Philips, 1999, p. 2], who depict discourse "as a system of texts that bridges an object into being (...) Discourse is therefore the foundation of the process of social construction upon which social reality depends". In terms of organization, in discourse analysis, "the communicative practice of members are examined for the ways that they contribute to the ongoing (and sometimes rather precarious) process of organizing” [Mumby and Robin, 1997, p. 181].

The work on data collection was conducted in accordance with the assumptions of discourse analysis. After the semistructured interviews were transcribed ${ }^{6}$, the key phrases were found in the text. As a result, 176 codes were identified, which were then grouped in 75 categories (second-level coding). Before the categories were labeled, all of them were revised and filtered; therefore, at the third stage of coding, 23 categories were labeled (first-order categories), which then were adjusted into second-order themes (six themes were identified). The theoretical dimension was achieved by searching for connections and relations between categories, which is presented in Table 2.

Apart from the interviews, supplementary data sources were also reviewed. These sources included information on the support organizations' websites and their promotional materials, which allowed the comparison of materials from interviews with formal texts.

Table 2. Data Structure

\begin{tabular}{|c|c|c|}
\hline First-Order Categories & Second-Order Themes & Theoretical Dimension \\
\hline $\begin{array}{l}\text { 1. Statutory assumptions } \\
\text { 2. Relations with local society/members/clients } \\
\text { 3. Brand perception }\end{array}$ & Role in a business society & \\
\hline $\begin{array}{l}\text { 4. Local and regional policy } \\
\text { 5. National policy } \\
\text { 6. EU support } \\
\text { 7. Features of regional support system }\end{array}$ & Position among policy actors & Legitimacy \\
\hline $\begin{array}{l}\text { 8. Equal access to support services } \\
\text { 9. High-quality services } \\
\text { 10. Free of charge or preferential price of services } \\
\text { 11. Easy access to support }\end{array}$ & Mission-related values & Value creation \\
\hline $\begin{array}{l}\text { 12. Sponsors } \\
\text { 13. EU programs } \\
\text { 14. Improving competences of employees } \\
\text { 15. Survival needs }\end{array}$ & Resource-dependent values & \\
\hline $\begin{array}{l}\text { 16. Equality } \\
\text { 17. Bottom-up activities } \\
\text { 18. Self-government initiatives }\end{array}$ & Logic of democracy & \\
\hline $\begin{array}{l}\text { 19. Policy-oriented services } \\
\text { 20. Public financing } \\
\text { 21. Services shaped by EU programs }\end{array}$ & Logic of the state & Conflicting institutional logics \\
\hline $\begin{array}{l}\text { 22. Achievement of results } \\
\text { 23. Cost and revenues of services } \\
\text { 24. Paid services for business }\end{array}$ & Logic of capitalism & \\
\hline
\end{tabular}

Source: Author. 


\title{
4.1 Findings
}

Taking into account the interviews from Szczecin and Glasgow, one should notice that distinction between quangos and NPOs is mainly observed in terms of self-centered and developmental needs. Quangos usually do not see many problems with financing of their needs, which are covered by establishing bodies. The evidence of such conclusion can be found in some quotes, for instance,

Needs? ' $3 G$ ' is funded by the government. (laugh)

Another quango (3S) underlines that the need for modernizing the building, which stands out among the average standards of office, is urgent and then adds that "money is never enough".

NPOs underline financial needs, indicating the possibilities of development services for businesses that are limited by access to finance. $1 \mathrm{G}$ indicates:

Yes, of course, we would like to develop our organization. Therefore, access to finance is a key issue. Our services are provided by people, and human resources cost. I would also be interested in getting new technology so that we could increase the efficiency of our services by using IT solutions. We have a list of ideas. But access to money is a problem (...) generally.

It is worth to add that $1 \mathrm{G}$ also admits the following: "We need to act like a real company. (...) we have to focus on profits, which enable us to finance our organization. We don’t want to rely only on public programs”. One Polish interviewee (2S) indicates that it is difficult to find funding for services other than the EU programs. "Our services are fully dependent on various EU or national programs", says $2 \mathrm{~S}$. $1 \mathrm{~S}$ provides an explicit example of the tensions between the mission and the development needs.

\begin{abstract}
It's hard to act as a nonprofit organization and provide services for business. It was business, I mean entrepreneurs, who established our organization. They expect high-quality services, which are up-to-date with the newest trends. That costs. (...) We've tried to get some money from sponsors or from the EU programs. Sponsors can pay for experts, but they expect us to invite a very specified group of firms and also book some time of the training for the sponsor's presentations. Companies don't like when they are interrupted with promotional activities or when we can't invite all who are interested in the topic of the training. This is the reality. (pause). Many times we feel awkward. (...) The same with the EU programs supporting SME development, in which we try to get involved. On the face of it, they can bring a lot of support to companies. But, in reality, very strict rules of realization of the projects affect the value of the deliverables, which meets only the expectations of the EU, not the entrepreneurs. The truth is that EU programs, which were elaborated in the past, are rarely up-to-date with current business needs. (pause) Anyway, it’s a very important financial support for our organizations.
\end{abstract}

Taking this view into account, the strongest tensions between financing and mission delivery can be observed among the NPOs. Interviews provide evidence of a gap between the vision of providing support for business and the financial capacities of the support organizations. But, in order to generalize about support organizations encompassing NPOs and quangos, quangos themselves deserve a closer look.

Seemingly, quangos act effectively and in accordance with their missions, as they were established to deliver the economic strategies. They are perceived as support organizations financed by public money with the mission to help any business that is interested in such help. In reality, many quangos are constrained by strategies and current government/EU programs. As 3G says: “There are some sectors in which we don't see much employment growth. Raising numbers is important for us". Therefore, the value of their offer is often targeted at selected sectors, while some sectors are even neglected ${ }^{7}$. In consequence, they cannot provide help for all, and hence they are often criticized about unfair support division. To survive for quangos means to act strictly according to the assumptions of the realized programs/strategies, which ensure financing.

Based on the assumption that all support organizations are perceived with a charitable mission to serve SMEs, the main associations with the value of the support services are equitable and easy access, as well as charge-free nature. This general understanding of the mission of support organizations is in reality

7 The majority of EU programmes excluded companies representing transport sector from applying for EU money for investments. 
modified by the survival and development needs, which vary depending on whether support organizations are NPOs or quangos. Thus, Proposition 1 that the value of services provided by support organizations is affected by the conflict emerging from tensions between resource dependency and prevention from drift in mission is proved.

The gathered data allows exploring the findings through the prism of the institutional logics proposed by Friedland and Alford [1991] and Thornton and Ocasio [2008]. All participants of the research claim the importance of the logic of profession, which can be demonstrated by the following quotes: "Our advisors are professionals. This approach is embedded in business culture, I think" (3G); or "Our staff has a professional experience in co-operations with business. We also collaborate with many experts from different fields" (1S). This logic shapes these organizations and hence influences the value of services.

Examining the group of NPOs, the democratic values appear in their discourse. $1 \mathrm{G}$ associates them with their charity work of collecting money from entrepreneurs for people who need them in a local community. "Establishing of (...) (1S) is a result of democratic activity of entrepreneurs, so called bottom-up initiative. We have to support our members, who have democratic power to control our functioning. Besides, we've been engaged in many regional issues related to economic development”, says 1S. The opposite of the logic of democracy is the logic of the state, which can be observed among all the interviewed NPOs. Already-cited quotes indicate the role of the EU and regional programs in the value creation of services. Apparently, the dependency on this type of financing is very strong, in one case, even creating the value of the entire offer (2s). The source dependency can also redefine the main target group. $2 S$ gives such an example: "Once we were focused on long-term unemployed people and even prisoners. (...) We were providing training, improving their job competences. (...) Because of money, we had to adjust to the available EU and regional programs". The existence of two opposite logics: democracy and the state, demonstrates that value creation is affected by conflicting institutional logics. What is more, exercising the logic of capitalism also kindles this conflict, as the logic of capitalism denies the logic of the state or democracy. The previously cited quotes about sponsorships can be followed by quotes describing the commercial activity of NPOs. 1G says, "We offer commercial services, especially for those institutions that wish to use our experience in supporting SMEs and the knowledge about them. We charge for analysis or reports. It helps our organization a lot”. 2G also admits that the work of their experts related to market analysis has a commercial price. $2 \mathrm{~S}$ states that they rent some of their rooms for commercial clients. $1 \mathrm{~S}$ concludes, "In my opinion, commercial activity is inevitable. It has an influence on our survival. On the one hand, it reshapes the whole value creation process by adjusting it to the commercial clients' needs. But on the other hand, earned money contributes to the services delivered to our target group".

Even though the logic of the state prevails among quangos, they seem to have enacted the logic of capitalism. "All industries are important, although the government prefers to prioritize something to focus on, to intensify the speed of growth potential, so we can go to invest and export. (...) We are all interested in sustainable results”, admits 3G. This is clear evidence that quangos are very result oriented; therefore, their value proposition is shaped not only by the goals of the state or regional strategies but also by the necessity of achieving results. Therefore, their value proposition is closely related to the feasibility of assumed indicators, e.g., investments in new technologies, export activities, and so on. In reality, support services are mainly provided for those who, for instance, are about to internationalize, even without such support, and not for those who have the potential to export goods but need more time for this. Such an approach illustrates the conflict between the logic of the state (mission delivery) and the logic of capitalism (achievement of the results).

These examples prove Proposition 2, which states that conflict among the logics of the state, capitalism, and democracy influences the value proposition of services offered by support organizations.

\section{Conclusion}

Value creation undertaken by support organizations does not directly reflect their missions. Even though one can generalize that all support organizations should adjust their offer according to the idea of helping 
companies (especially SMEs) in their development, support organizations very often struggle with the conflict between mission delivery and survival needs. The existence of competing values, which ultimately create the value proposition of support organizations, can be explained by the interference of conflicting institutional logics. Institutional logics, embedded in social systems, govern all social agents. The logics of capitalism, democracy, and the state, despite their antagonistic nature, coexist and overlap on the process of value creation taking place in business support organizations.

The idea of a supporting system is generally perceived as a provision of services (a charge-free service or at preferential prices), which can help companies in their development. Therefore, the values associated with such services are accessibility, equality, high quality, professional, and also up-to-date nature (reflecting turbulent environment). Such values prevail in the missions of support organizations. Nevertheless, as the study shows, support organizations have to struggle with survival needs. As a result, the value creation of their services is influenced by different institutional logics and, therefore, the value proposition very often does not emerge purely from their missions but is redefined by the main money sources. The study provides examples of how institutional logic of the state (EU or state programs, strategies), institutional logic of capitalism (commercial activity, survival and development needs, strong result orientation), and logic of democracy (bottom-up initiatives, representing the interests of founders) are interrelated and, therefore, interfere on the value creation of services (Figure 2).

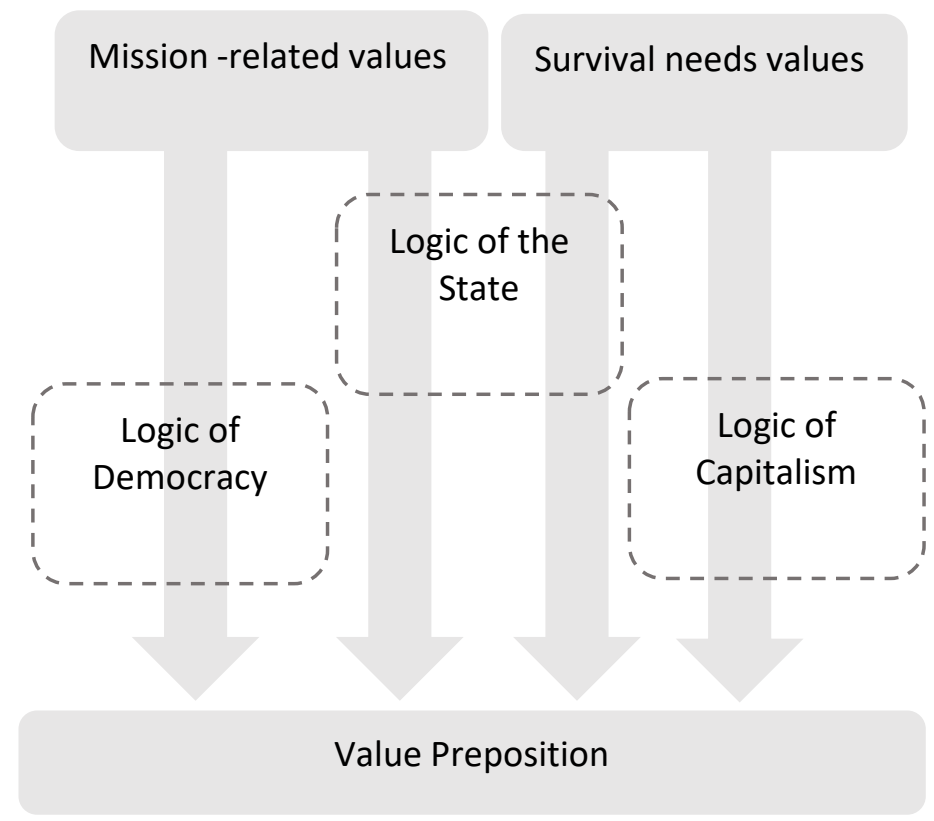

Figure 2. The influence of competing institutional logics on the value creation of business support organizations. Source: Author.

The study also contributes to the understanding of the nature of two main types of support services (quangos and NPOs), which reflects the dominance of specific institutional logics and, hence, their influence on the value creation. These conclusions also provide valuable insights proving that the line between the market sector and the third sector - and even the public sector (quangos) - is blurring. The distinction between what is purely a nonprofit service and what emerges purely from public policy can be difficult due to resultoriented approach and survival needs of support organizations. Institutional logics that govern business support organizations can be utilized to explore the issue of sectoral duality in further studies.

Exploring resource dependency theory, together with the influence of isomorphism on value creation, seems to be another interesting issue for future research on business support organizations. As shown herein, mission-related values are often dominated by survival needs in the case of business support 
organizations. The resource dependency theory assumes that organizations are not autonomous but constrained by multiple relations and interdependencies with other actors. When organizations undertake actions to manage the uncertainty resulting from relations with other organizations, they in fact get involved in new networks of new interdependencies [Pfeffer, 1987]. Taking this into account, one may say that noncommercial missions of support organizations are doomed to failure as these organizations function in the commercial market and are partially dependent on commercial relations.

What is more, considering a potential influence of isomorphism (tendency to homogeneity), identified by DiMaggio and Powel [1983], another area of convergence can be noticed. Conflicting institutional logics, combined with resource dependency theory, seem to have much in common with three types of isomorphism. Normative isomorphism should be investigated among the executive management of support organizations in order to find out how their professionalism shapes their organizations (data on education and former experience was not collected in the research). Mimetic isomorphism seems to overlap with resource dependency theory and the logic of capitalism. Coercive isomorphism does have the potential to contribute to understanding the influence of the institutional logic of the state.

Summing up, I hope I would encourage scholars for conducting further research exploring the complex nature of business support organizations.

Acknowledgment: I am grateful for the research assistance of Professor Colin Mason of the University of Glasgow and for the support of Dr. Sabina Siebert of the University of Glasgow.

\section{References}

Agafonow, A. (2014/2015), Value creation, value capture, and value devolution: where do social enterprises stand? Administration \& Society, Vol. 47, No. 8, p. 1038.

Battilana, J., Dorado, S. (2010), Building sustainable hybrid organizations: the case of commercial microfinance organizations, Academy of Management Journal, Vol. 53, No. 6, pp. 1419-1440.

Bochel, C., Bochel, H.M. (2004), The UK social policy process, Palgrave Macmillan, Houndmills.

Bradshaw, P. (2009), A contingency approach to nonprofit governance, Nonprofit Management \& Leadership, Vol. 20, No. 1, pp. 61-81.

Bridge, S., Murtagh, B., O'Neill, K. (2009/2014), Understanding the social economy and the third sector, Palgrave Macmillan, New York, NY.

Carroll, G. (1988), Ecological models of organizations, Ballinger, Cambridge, MA.

Ceyert, R.M., March, J.G. (1963), A behavioural theory of the firm, Prentice Hall, Englewood Cliffs, NJ.

Clarke, J., Newman, J., Smith, N., Vidler, E., Westmarland, L. (2007), Creating citizen-consumers: changing publics and changing public services, Sage, London.

Commission Staff Working Paper Sec. (2001), Creating top-class business support services, Commission of The European Communities, Brussels. 28.11.2001 14829/01.

DiMaggio, P. (2006), Nonprofit organizations and intersectoral division of labour in the arts, in: W.W. Powell, R. Steinberg, (Eds), The non-profit sector: a research handbook, 2nd edn, Yale University Press, London, England, pp. 140-158.

DiMaggio, P.J., Powell, W.W. (1983), The iron cage revisited: institutional isomorphism and collective rationality in organizational fields, American Sociological Review, Vol. 48, No. 2, pp. 147-160.

Doig, A. (1979), The machinery of government and the growth of governmental bodies, Public Administration, Vol. 15, pp. 209-231.

Donaldson, L. (2001), The contingency theory of organizations, Sage, Thousand Oaks, CA.

du Gay, P. (2000), Markets and meaning: re-imagining organizational life, in: M. Schultz, M.J. Hatch, M.H. Larsen, (Eds), The expressive organization: linking identity, reputation, and the corporate brand, Oxford University Press, Oxford.

Eikenberry, A., Klover, J. (2004), The marketization of the nonprofit sector: civil society at risk? Public Administration Review, Vol. 64, No. 2, pp. 132-140.

Evers, A. (2005), Mixed welfare systems and hybrid organizations: changes in the governance and provision of social services, International Journal of Public Administration, Vol. 28, No. 9-10, pp. 737-748.

Ferris, J., Graddy, E. (1999), The role of the nonprofit sector in a self-governing society: a view from the United States, Voluntas, Vol. 9, pp. 137-154.

Flinders, M. (2004), Icebergs and MPs: delegated governance and parliament, Parliamentary Affairs, Vol. 57, No. 4, pp. 767-784. 
Friedland, R., Alford, R.R. (1991), Bringing society back in: symbols, practices, and institutional contradictions, in: W.W. Powell, P.J. DiMaggio, (Eds), The new institutionalism in organizational analysis, University of Chicago Press, Chicago, pp. 232-266.

Grant, D., Hardy, C., Oswick, C., Putnam, L. (Eds). (2004), The SAGE handbook of organizational discourse, SAGE, London.

Greenwood, R., Díaz, A.M., Li, S.X., Lorente, J.C. (2010), The multiplicity of institutional logics and the heterogeneity of organizational responses, Organization Science, Vol. 21, pp. 521-539.

Greenwood, R., Raynard, M., Kodeih, F., Micelotta, E.R., Lounsbury, M. (2011), Institutional complexity and organizational responses, The Academy of Management Annals, Vol. 5, No. 1, pp. 317-371.

Gunn, C. (2004), Third-sector development: making up for the market, ILR Press/Cornell University Press, London/Ithaca, NY.

Hailey, J.M. (1985), Enterprise support organisations in the south pacific, International Journal of Manpower, Vol. 6, No. 4, pp. 28-31.

Hammack, D., Young, D. (Eds). (1993), Non-profit organizations in a market economy, Jossey Bass, San Francisco, CA.

Hannan, M.T., Freeman, J. (1977), The population ecology of organizations, American Journal of Sociology, Vol. 82, No. 5, pp. 929-964.

Hardy, C., Phillips, N. (1999), No joking matter. Discursive struggle in the Canadian refugee system, Organization Studies, Vol. 20, pp. 1-24.

Jay, J. (2012), Navigating paradox as a mechanism of change and innovation in hybrid organizations, Academy of Management Journal, Vol. 56, No. 1, pp. 137-159.

Jones, C., Maoret, M., Massa, F.G., Svejenova, S. (2012), Rebels with a cause: formation, contestation, and expansion of the de novo category “modern architecture," 1870-1975, Organization Science, Vol. 23, No. 6, pp. 1523-1545.

Knapp, M., Beecham, J., Haliam, A. (1997), The mixed economy of psychiatric reprovision, in: J. Leff, (Ed), Care in the community: illusion or reality?, Wiley, London.

Knutsen, W.L. (2012), Adapted institutional logics of contemporary nonprofit organizations, Administration \& Society, Vol. 44, No. 8, pp. 985-1013.

Manjula, S., Raymond, J. (2011), Population ecology theory: implications for sustainability, Management Decision, Vol. 49, No. 6, pp. 874-910.

Markiewicz, J. (2010), Instytucje otoczenia biznesu. Rola w ksztattowaniu innowacyjności sektora MSP na przykładzie województwa zachodniopomorskiego, Wydawnictwo Naukowe Uniwersytetu Szczecińskiego, Szczecin.

McGarvey, N., Cairney, P. (2008), Scottish politics. An introduction, Palgrave Macmillan, Basingstoke.

Mumby, D., Robin, P.C. (1997), in: T.A. van Dijk, (Ed), Organisational discourse in discourse as social interaction, Sage, London, pp. 181-205.

North, D.C. (1990), Institutions, institutional change and economic performance, Cambridge University Press.

Osborne, S.P. (2006), The new public governance? Public Management Review, Vol. 8, No. 3, pp. 377-387.

Pache, A.C., Santos, F. (2013), Inside the hybrid organization: selective coupling as a response to competing institutional logics, Academy of Management Journal, Vol. 56, No. 4, pp. 972-1001.

Payne, A., Frow, P. (2014), Deconstructing the value proposition of an innovation exemplar, European Journal of Marketing, Vol. 48, No. 1/2, pp. 237-270.

Pfeffer, J. (1987), A resource dependence perspective on interorganizational relations, in: M.S. Mizruchi, M. Schwartz, (Eds), Intercorporate relations: the structural analysis of business, Cambridge University Press, Cambridge, UK, pp. 22-55.

Pfeffer, J., Salancik, G.R. (1978), The external control of organizations: a resource dependence perspective, Harper \& Row, New York.

Phillips, N., Lawrence, T., Hardy, C. (2004), Discourse and institutions, Academy of Management Review, Vol. 29, No. 4, pp. 635-652.

Public Finance Act. (2009), Dz.U. 09.157.1240.

Reay, T., Hinings, C.R. (2009), Managing the rivalry of competing institutional logics, Organization Studies, Vol. 30, No. 06, pp. 629-652.

Rintamaki, T., Kuusela, H., Mitronen, L. (2007), Identifying competitive customer value propositions in retailing, Managing Service Quality, Vol. 17, No. 6, pp. 621-634.

Selznick, P. (1949), TVA and the grass roots: a study in the sociology of formal organization, University of California Press, Berkeley.

Skelcher, C. (1998), The appointed state: quasi-governmental organizations and democracy, Open University Press, Buckingham.

Spicer, A., Sewell, G. (2010), From national service to global player: transforming the organizational logic of public broadcaster, Journal of Management Studies, Vol. 47, No. 6, pp. 913-943.

Thornton, P.H., Ocasio, W. (1999), Institutional logics and the historical contingency of power in organizations: executive succession in the higher education publishing industry, 1958-1990, American Journal of Sociology, Vol. 105, pp. 801-843.

Thornton, P.H., Ocasio, W. (2008), Institutional logics, in: G. Royston, O. Christine, S. Kerstin, S. Roy, (Eds), Handbook of organizational institutionalism, Sage, CA. 
Thornton, P.H., Ocasio, W., Lounsbury, M. (2012), The institutional logics perspective: a new approach to culture, structure and process, Oxford University Press, Oxford, UK.

Vaara, E., Sorsa, V., Pälli, P. (2010), On the force potential of strategy texts: a critical discourse analysis of a strategic plan and its power effects in a city organization, Organization, Vol. 17, No. 6, pp. 685-702.

Veblen, T. (1899), The theory of the leisure class, Penguin Books, New York, NY.

Wright, A. (1994), The quangos quagmire, The Guardian. 